\title{
Elephant population growth in Kruger National Park, South Africa, under a landscape management approach
}

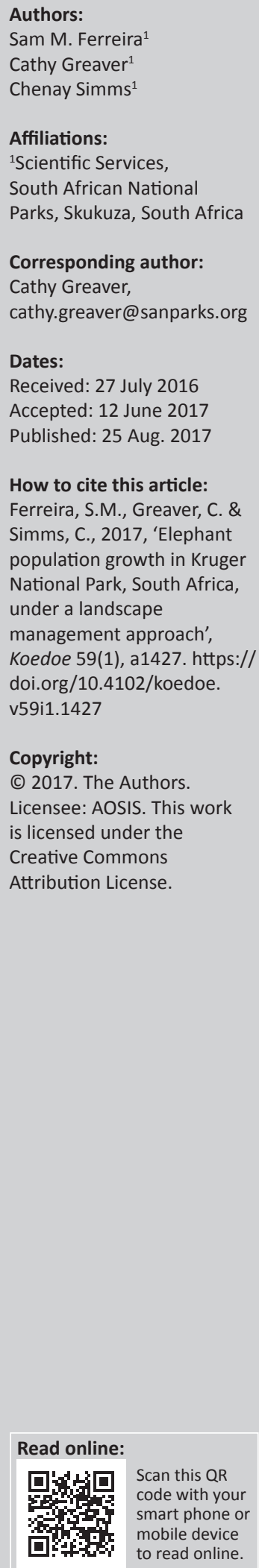

South African National Parks (SANParks) manage landscapes rather than numbers of elephants (Loxodonta africana) to mitigate the effects that elephants may have on biodiversity, tourism and stakeholder conservation values associated with protected areas. This management philosophy imposes spatial variability of critical resources on elephants. Restoration of such ecological processes through less intensive management predicts a reduction in population growth rates from the eras of intensive management. We collated aerial survey data since 1995 and conducted an aerial total count using a helicopter observation platform during 2015. A minimum of 17086 elephants were resident in the Kruger National Park (KNP) in 2015, growing at $4.2 \%$ per annum over the last generation of elephants (i.e. 12 years), compared to $6.5 \%$ annual population growth noted during the intensive management era ending in 1994. This may come from responses of elephants to density and environmental factors manifested through reduced birth rates and increased mortality rates. Authorities should continue to evaluate the demographic responses of elephants to landscape scale interventions directed at restoring the limitation of spatial variance in resource distribution on elephant spatiotemporal dynamics and the consequences that may have for other conservation values.

Conservation implications: Conservation managers should continue with surveying elephants in a way that allows the extraction of key variables. Such variables should focus on measures that reflect on how theory predicts elephants should respond to management interventions.

\section{Introduction}

African savanna elephants (Loxodonta africana) significantly influence several conservation management objectives that authorities seek to achieve in protected areas. Managers of protected areas typically seek to conserve biodiversity - elephants act as ecological engineers that may alter habitats and various aspects of biological diversity (Valeix et al. 2011). Protected areas also serve as focal places where elephant presence forms a key component of tourist attractions and experiences (Kerley, Geach \& Vial 2003). For people living next to parks, elephants leaving protected areas threaten livelihoods and lives (Osborn \& Parker 2003). South African National Parks (SANParks) seek to manage these effects that elephants have on the ability of managers to achieve conservation management objectives.

The effects that elephants have on biodiversity, tourist experiences and rural people's livelihoods may associate primarily with their location rather than abundance or density (Van Aarde, Jackson \& Ferreira 2006). In small parks, however, density of elephants may aggravate the effects they have on biodiversity. The way elephants use landscapes depends on the distribution of water (Chamaillé-Jammes, Valeix \& Fritz 2007; Loarie, Van Aarde \& Pimm 2009), food (Codron et al. 2006) and shade (Kinahan, Pimm \& Van Aarde 2007) - resources that elephants select at different intensities during different seasons (Young, Ferreira \& Van Aarde 2009a). In addition, elephants avoid people by choice (Douglas-Hamilton, Krink \& Vollrath 2005; Graham et al. 2009). Within this context SANParks embraced a landscape approach to elephant management and seek to restore the landscape variability and limitations on elephant spatial and temporal dynamics (Harris et al. 2008). Within Kruger National Park (KNP), this translated to stopping the control of elephant numbers through culling (Van Aarde, Whyte \& Pimm 1999), the closure of boreholes and destruction of several earthen dams (Gaylard, Owen-Smith \& Redfern 2003), the removal of fences between Kruger National Park and adjacent conservation-friendly land-uses (Venter, Naiman, Biggs \& Pienaar 2008), and the use of a fire management policy focusing on patch burns (Van Wilgen et al. 2004).

The creation of spatial and temporal heterogeneity in elephant resources predicts responses in how elephants use landscapes. Elephants use landscapes more variably (Smit \& Ferreira 2010) 
following the restoration of various ecological processes, where previous management philosophies and approaches fostered homogeneity (Venter et al. 2008). Variability in landscape use also predicts population numerical responses - when daily distances travelled by cows increase, weaned calves have higher mortality rates (Young \& Van Aarde 2010). The closure of boreholes increased distances and configuration (Gaylard 2015) required for travel between water and good quality food. In addition, when SANParks stopped culling, elephant densities increased (Van Aarde, Whyte \& Pimm 1999). Higher densities associated with a less clumped distribution of elephants across the Kruger landscape (Young, Ferreira \& Van Aarde 2009b). These mechanisms predict decreased population growth rates with increasing density and decreasing water provisioning.

SANParks seek to evaluate the consequences of reduced management intensity directed at mitigating the effects of elephants on various conservation management objectives. Monitoring focuses on spatial and temporal responses of elephants. As part of this monitoring, SANParks survey elephants to derive estimates of population variables. Here we report on the KNP elephant survey of 2015, trends extracted from recent surveys (SANParks, Unpublished data $^{1}$ ) and check population growth rates post 1994 against those at the end of the intensive elephant management era in the mid-1990s (Whyte 2001).

\section{Methods}

The KNP, $19485 \mathrm{~km}^{2}$ in size, spans the low-lying savannas of the eastern parts of the Limpopo and Mpumalanga Provinces, South Africa. Mozambique abuts the Park in the east, while Zimbabwe forms the boundary to the north. The Park has a mean annual rainfall that varies from $750 \mathrm{~mm}$ in the south to $450 \mathrm{~mm}$ in the north, with $\pm 80 \%$ of rain falling during summer (Gertenbach 1980). Granite and gneiss soils dominate $\mathrm{KNP}^{\prime} \mathrm{s}$ western half and nutrient-rich basalt soils dominate the eastern half, with a narrow band of Karoo sediment occurring at the junction of the granite and basalt (Schutte 1986). The vegetation on the southern basalts is largely wooded savanna, with Sclerocarya caffra and Vachellia nigrescens dominating the tree canopy. Mixed Combretum spp. and Vachellia spp. dominate the southern granites. In the north Colophospermum mopane dominates both the basalt and granite substrates (Gertenbach 1983). This produces a diverse range of landscapes resulting in spatial and temporal heterogeneity of resources that elephants use.

Water is an essential resource provided through several perennial (i.e. Crocodile, Sabie, Olifants and Letaba) and large seasonal rivers (i.e. Biyamiti, Nwaswitshaka, Nwatswitsontso, Timbavati, Tsendze, Shingwedzi, Levhuvhu and Limpopo). The provision of additional water, through drilling of boreholes and construction of several dams that started in 1933, disrupted spatial and temporal heterogeneity 1.SANParks Data Depository, Judith Botha, judith.botha@ @ sanparks.org of water availability and quality. KNP had 365 boreholes (Gaylard, Owen-Smith \& Redfern 2003) and 109 pipeline troughs, weirs, concrete and earthen dams by 1995. Since then, the closure of boreholes, breaching of dams and removal of structures resulted in 41 boreholes and 31 pipeline troughs, weirs, concrete and earthen dams remaining functional during our study. ${ }^{2}$

We applied a total count approach to survey elephants living in KNP during 2015, using the same technique as used by SANParks since 1967 (Whyte 2001). The approach divides the Park into 21 blocks and uses a helicopter-based observation platform to search each block for elephants. Flight paths, flown at 90-100 knots at a height of $91 \mathrm{~m}$ above ground level, focused on 2nd order river catchments approximately $500 \mathrm{~m}-1000 \mathrm{~m}$ parallel to the second order stream. The distance between flight paths vary depending on vegetation cover. We used two helicopters to survey blocks during August 2015 over a 21-day period. Each helicopter, surveying a separate block, was crewed by a pilot, two observers and a person recording data. The survey team noted the geo-referenced positions of elephant groups encountered, recorded the number of elephants in the group, identified the group as a bull or mixed herd and counted calves less than 1 year old (see Trimble et al. 2011) for mixed herds.

From these surveys, we summed all observations to find the total number of elephants observed. We collated the total number of elephants observed in surveys since 1995. These values are estimates of minimum numbers of elephants known to be alive and do not account for availability, detection probability, observer bias or statistical sampling error (Caughley 1974).

We fitted population models that included exponential:

$\left(N_{t}=N_{0} e^{r t}\right)$,

[Eqn 1]

Ricker:

$\left(N_{t+1}=N_{t} e^{r_{m}\left(1-\left(N_{t} / K\right)\right.}\right)$

[Eqn 2]

and heterogeneity:

$\left(N_{i, t+1}=N_{i, t} e^{r_{m}\left(1-\left(N_{i, t} / \alpha_{i} R\right)\right.}\right)$

models where $N_{t}$ is minimum number of elephants alive at time $t, r$ is exponential growth rate, $r_{m}$ is maximum growth rate, $K$ is an estimate of equilibrium population size, $R$ is mean annual rainfall and $\alpha$ is a constant. We estimated $r, r_{m^{\prime}} K$ and $\alpha$ using maximum likelihood approaches (Edwards 1972; Microsoft Excel macro provided by Hood 2005). We used Akaike's Information Criteria (AIC) to select the most appropriate model (Johnson \& Omland 2004). When differences between $A I C_{c}$ values were less than 2, we used model averaging (Claeskens \& Hjort 2008)

2.SANParks Kruger National Park Conservation Management, Stephen Midzi, stephen.midzi@sanparks.org 
to obtain a population growth estimate and associated confidence intervals.

The recording of calves allowed us to derive a recruitment rate as the fraction of elephants less than 1 year old. Such a recruitment rate is the consequence of calves born and their subsequent survival during the first year. To estimate overall elephant survival (s) we calculated an age distribution parameter $a$, the rate at which age-specific frequencies decay with age in stable age distributions from:

$$
\sum_{x}^{w} n_{x}=n_{0} a^{x}\left[\frac{\left(1-a^{(w-x+1)}\right)}{(1-a)}\right]
$$

where $n_{x}$ is the frequency of individual $x$ years of age and $w$ is elephant longevity (Ferreira \& Van Aarde 2008). We set $w$ at 55 years (Lee et al. 2016). We estimated $a$ using maximum likelihood approaches (Edwards 1972; Microsoft Excel macro provided by Hood 2005). This allowed us to calculate survival from $a=\lambda s$ (Eberhardt 1988) where $\lambda$ is finite population growth $(\lambda=1+r)$. To minimise the consequences of variation in age distributions, we recalculated population growth using only estimates spanning an elephant generation defined as the age at which member of a given cohort is expected to reproduce (Charlesworth 1994), that is, 12 years (Robson 2015) from 2004 until 2015 and used this as input to calculate survival rate. We could then estimate birth rate by dividing recruitment rate with the average estimated survival rate across all age classes.

SANParks' intensive management philosophy ceased in 1994 that is, culling stopped, water provisioning decreased, some fences were removed and patch burns were implemented since then. We thus extracted population growth rates as well as estimates of survival and recruitment rates prior to 1994 (Whyte 2001) to check against recent estimates of these variables. Note that mean annual rainfall prior to 1994 was $510.1 \mathrm{~mm}(\mathrm{SE}=38.2, n=18)$ similar to that after culling stopped (565.1, SE $=44.5, n=20)$ and from 2004 to 2015 (529.4, $\mathrm{SE}=34.0, n=11)$. We thus did not consider rainfall driven influences in our comparisons.

\section{Results and discussion}

We encountered elephants throughout KNP (Figure 1). Two of the large perennial rivers dissecting the Park - the Olifants and Sabie Rivers served as boundaries for regional estimates. We provide estimates for areas north of the Olifants River, between the Olifants and Sabie Rivers and south of the Sabie River separately. Observers encountered 7107 and 1163 elephants in mixed $(n=527)$ and bull herds $(n=546)$, respectively, north of the Olifants River at a density of $0.84 \mathrm{n} . \mathrm{km}^{-2}$. Between the Sabie and Olifants Rivers observers noted 3526 and 462 elephants living in mixed $(n=289)$ and bull herds $(n=229)$, respectively, at a density of $0.81 \mathrm{n} . \mathrm{km}^{-2}$. Highest density of $1.15 \mathrm{n} . \mathrm{km}^{-2}$ was south of the Sabie River and came from observers recording 4232 and 596 elephants in mixed $(n=306)$ and bull herds $(n=302)$, respectively. These regional counts resulted in a minimum of 17086 elephants living in KNP during 2015.

Models describing the trends in minimum elephants known to be alive after culling stopped were equivalent $\left(r^{2}\right.$ values ranged from 0.96 to 0.98$)$ (Table 1). Model averaging (Figure 2) thus recorded annual exponential growth rate since 1995 at $4.9 \%(2.1 \%-7.6 \%)$ per annum, similar to that reported previously (Young et al. 2009b). The point estimates of $6.5 \%$ reported prior to 1995 (Whyte 2001), the period of intensive management, is located at the 86.7 th percentile of growth since 1995. Population growth since 2003, an elephant generation, was $4.2 \%(1.1 \%-7.3 \%)$ with $6.5 \%$ located at the 92.7 th percentile of growth since 2004 . These results may reflect a likely reduction in elephant population growth rate over time and as densities increased supporting the prediction that population growth rates should be declining. Note that poaching had little effect on the elephants living in KNP with between 0 and 22 elephants poached during any year (SANParks, unpublished data ${ }^{3}$ ). It is uncertain, however, how poaching of elephants could change in future and what the impact would be on the population in KNP.

We acknowledge that movements of elephants to areas abutting KNP can also account for reduction in population growth rates that we noted. For this reason, we also estimated vital rates given that previous studies implied variance in birth rates (Robson 2015) and declines in survival rates as mechanisms associated with increase landscape limitations on elephant resources (Young et al. 2009b; Young \& Van Aarde 2010). The estimated population growth since 2003 and an estimated age distribution parameter over that same period $(a=0.94 \pm 0.02, n=10)$ allowed us to estimate survival during the first year at 0.982 (0.941-0.999), while other age classes had a survival rate of $0.983(0.954-0.999)$. This estimate ignores agespecific survival rates for elephants older than 1 year. The overall recruitment rate $(5.67 \%, 5.23 \%-6.02 \%)$ predicted an annual birth rate of $5.78 \%(5.33 \%-6.41 \%)$. Note that during the period of intensive management estimates of annual birth rates (expressed as potential rates of increase i.e. rate of increase in the absence of mortality) ranged from $7.8 \%$ to $16.8 \%$ (Whyte 2001). Demographic responses of elephants to restoration of ecological processes may thus provide some potential mechanisms explaining how elephant growth rates declined since 1995. Recent analyses, however, highlight that variability reflecting on ecological productivity during the conception and gestation phases of elephant reproduction drives variability in elephant birth rates (Robson 2015).

The estimated survival rate translates to an overall mortality rate of $1.8 \%(1.72 \%-1.88 \%)$ higher than the point estimated of $1.5 \%$ reported for the period of intensive 3.Ken Maggs, ken.maggs@sanparks.org 


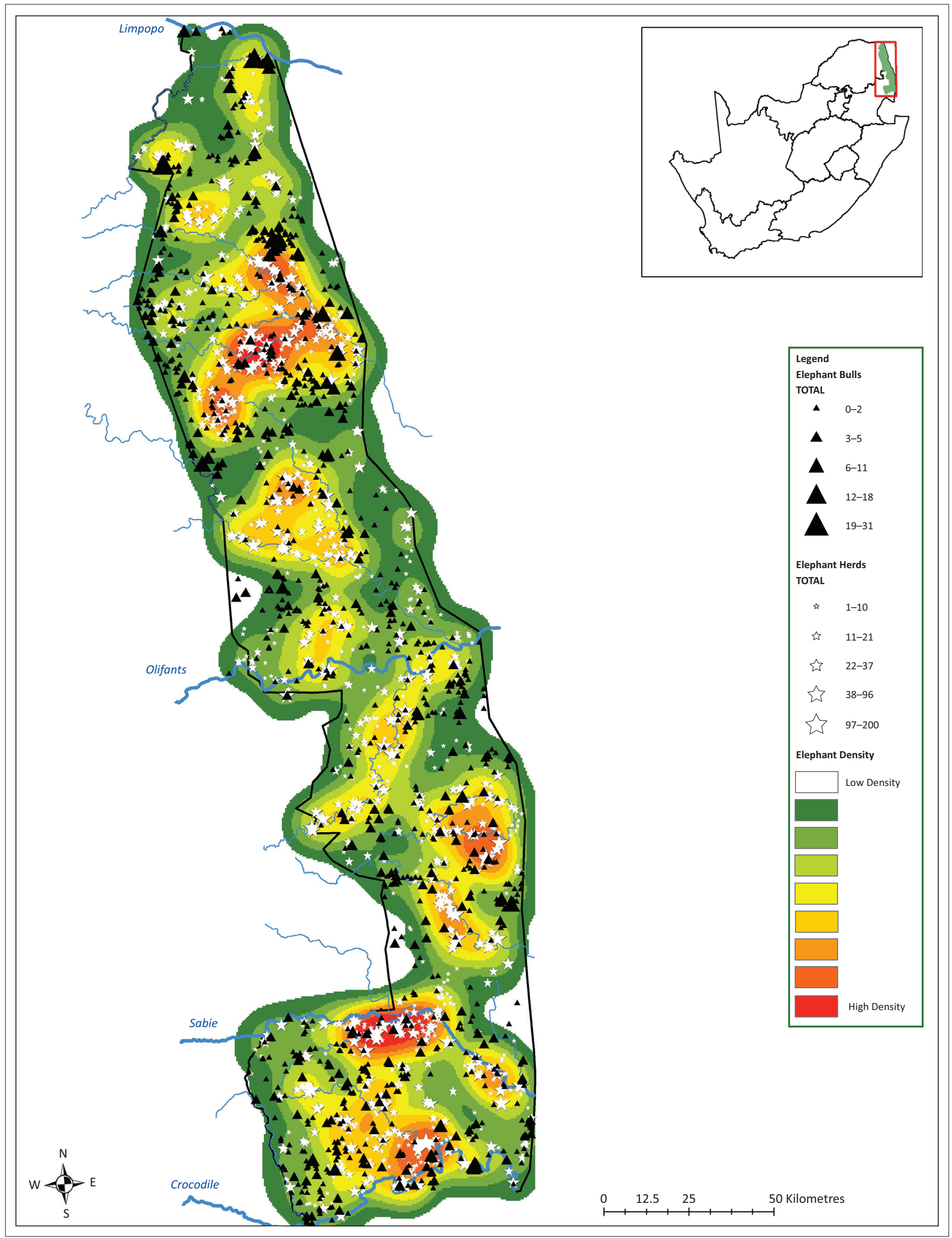

We indicate bulls (black) and mixed herds (white) separately with the symbol size indicating group size on a heat map reflecting elephant distribution in the Kruger National Park during the dry season, based on the actual locality of each observation.

FIGURE 1: The distribution of elephants recorded during the survey of the Kruger National Park in 2015. 
TABLE 1: Population model comparisons made for minimum number of elephants living in the Kruger National Park since 1995.

\begin{tabular}{|c|c|c|c|c|c|c|}
\hline Type of Model & Equation & $r^{2}$ & $A I C_{c}$ & $\Delta_{i}$ & $L_{i}$ & $w_{i}$ \\
\hline \multicolumn{7}{|l|}{ 1995-2015 } \\
\hline Exponential & $N_{t}=7884 e^{0.0401 t}$ & 0.960 & 13.73 & 0.57 & 0.75 & 0.27 \\
\hline Ricker & $N_{t+1}=N_{t} e^{0.0510\left(1-\left(N_{t} / 56189\right)\right.}$ & 0.961 & 13.19 & 0.02 & 0.99 & 0.36 \\
\hline Heterogeneity & $N_{i, t+1}=N_{i, t} e^{0.0544\left(1-\left(N_{i, t} / 92.01 R\right)\right.}$ & 0.962 & 13.17 & - & 1.00 & 0.36 \\
\hline \multicolumn{7}{|l|}{ 2004-2015 } \\
\hline Exponential & $N_{t}=7884 e^{0.0401 t}$ & 0.982 & 12.98 & 0.53 & 0.77 & 0.28 \\
\hline Ricker & $N_{t+1}=N_{t} e^{0.0510\left(1-\left(N_{t} / 56189\right)\right.}$ & 0.981 & 12.46 & 0.01 & 1.00 & 0.36 \\
\hline Heterogeneity & $N_{i, t+1}=N_{i, t} e^{0.0544\left(1-\left(N_{i, t} / 92.01 R\right)\right.}$ & 0.982 & 12.45 & 0.00 & 1.00 & 0.36 \\
\hline
\end{tabular}

Note: We illustrate comparisons for the 1995 to 2015 period as well as the 2004 to 2015 period.

$A I C_{c^{\prime}}$ Akaike Information Criteria corrected for small sample size; $\Delta_{i}$, difference from minimum $A / C_{i} ; L_{i}$, likelihood for model $i$ to be representative; $w_{i}$, weight of evidence to support model $i$.

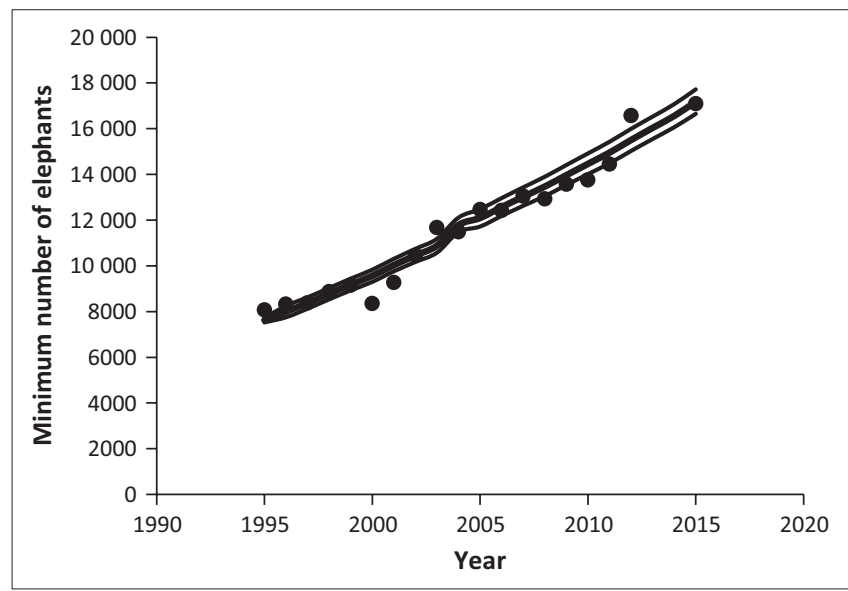

FIGURE 2: Minimum number of elephants living in the Kruger National Park since 1995 after intensive management of elephants stopped in 1994. We also illustrate the average model (line) and its $95 \%$ confidence intervals (thin lines) since then.

management (Whyte 2001). We are mindful of confounding influences of different methods, but our results could support the predictions derived from mechanism of how changes in resource distribution and density influence survival schedules of elephants (Young \& Van Aarde 2010). We acknowledge though that SANParks need estimates of age-specific survival to evaluate the various predictions made on how daily distances travelled as a result of variability in resources and elephant density influence survival of specifically weaned calves (Young \& Van Aarde 2010).

\section{Conclusion and recommendations}

The temporal responses of elephants following the implementation of a philosophy of managing landscapes rather than managing elephants directly (Van Aarde, Jackson \& Ferreira 2006) support the predictions that elephant population growth rate slows when elephant resources are heterogeneously distributed across the landscape.
A minimum of 17086 elephants were present in KNP during 2015 with their temporal dynamics reflecting declining growth rates coming from interactions between decreased birth and increased death rates. SANParks should continue monitoring elephants and check temporal responses complimented by demographic studies in concert with spatial responses derived through distribution and satellite studies. The association between elephant responses to management and the significance of elephants for biodiversity, tourism and stakeholder values associated with protected areas (but see Guldemond \& Van Aarde 2008) remains a key requirement.

\section{Acknowledgements}

We are grateful to the following observers: Sandra Visagie, Marius Snyders, Andrew Desmet, Joe Nkuna, Richard Sowry, Rob Thompson, Pauli Viljoen, Jacques Venter, Adolf Manganyi, Steven Oosthuizen, Scott Ronaldson, Ben Wigley, Corli Wigley, Izak Smit, Rudi Lorist and the pilots Grant Knight, Charles Thompson, Jaco Mol and Brad Grafton. We thank Dr Mike Chase, Director of Elephants Without Borders, who provided part of the funding through the Paul Alan Foundation. The remaining funding was provided from SANParks baseline funding.

\section{Competing interests}

The authors declare that they have no financial or personal relationships that may have inappropriately influenced them in writing this article.

\section{Authors' contributions}

C.G. coordinated the aerial survey but all authors participated in the aerial survey. S.M.F. performed the statistical analysis. C.S. performed the ArcGis analyses. S.M.F. led the writing while C.G. and C.S. assisted with writing and editing. 


\section{References}

Caughley, G., 1974, 'Bias in aerial survey', The Journal of Wildlife Management 38(4), 921-933. https://doi.org/10.2307/3800067

Chamaille-Jammes, S., Valeix, M. \& Fritz, H., 2007, 'Managing heterogeneity in elephant distribution: Interactions between elephant population density and surface-water availability', Journal of Applied Ecology 44(3), 625-633. https://doi. org/10.1111/j.1365-2664.2007.01300.x

Charlesworth, B., 1994, Evolution in age-structured populations, pp. 28-30, University of Cambridge Press, Cambridge.

Claeskens, G. \& Hjort, N.L., 2008, Model selection and model averaging, vol. 330, Cambridge University Press, Cambridge.

Codron, J., Lee-Thorp, J.A., Sponheimer, M., Codron, D., Grant, R.C. \& De Ruiter, D.J., 2006, 'Elephant (Loxodonta africana) diets in Kruger National Park, South Africa: Spatial and landscape differences', Journal of Mammalogy 87(1), 27-34. https:// doi.org/10.1644/05-MAMM-A-017R1.1

Douglas-Hamilton, I., Krink, T. \& Vollrath, F., 2005, 'Movements and corridors of African elephants in relation to protected areas', Naturwissenschaften 92(4), 158-163. https://doi.org/10.1007/s00114-004-0606-9

Eberhardt, L.L., 1988, 'Using age structure data from changing populations', Journal of Applied Ecology 25, 373-378. https://doi.org/10.2307/2403829

Edwards, A.W.F., 1972, Likelihood, Cambridge University Press, Cambridge.

Ferreira, S.M. \& Van Aarde, R.J., 2008, 'A rapid method to estimate population variables for African elephants', The Journal of Wildlife Management 72(3), 822-829. https://doi.org/10.2193/2007-151

Gaylard, A., 2015, 'Adopting a heterogeneity paradigm for understanding and managing elephants for biodiversity: A case study in riparian woodlands in Kruge National Park', PhD dissertation, University of the Witwatersrand, Johannesburg, South Africa.

Gaylard, A., Owen-Smith, N. \& Redfern, J., 2003, 'Surface water availability: Implications for heterogeneity and ecosystem processes', in J.T. du Toit, K.H. Rogers \& H.C. Biggs (eds.), The Kruger experience: Ecology and Management of Savanna Heterogeneity, pp. 171-188, Island Press, Washington, DC.

Gertenbach, W.D., 1980, 'Rainfall patterns in the Kruger National Park', Koedoe 23(1), 35-43. https://doi.org/10.4102/koedoe.v23i1.634

Gertenbach, W.D., 1983, 'Landscapes of the Kruger National Park', Koedoe 26(1), 9-121. https://doi.org/10.4102/koedoe.v26i1.591

Graham, M.D., Douglas-Hamilton, I., Adams, W.M. \& Lee, P.C., 2009, 'The movement of African elephants in a human-dominated land-use mosaic', Animal Conservation 12(5), 445-455. https://doi.org/10.1111/j.1469-1795.2009.00272.x

Guldemond, R. \& Van Aarde, R., 2008, 'A meta-analysis of the impact of African elephants on savanna vegetation', The Journal of Wildlife Management 72(4), 892-899. https://doi.org/10.2193/2007-072

Harris, G.M., Russell, G.J., Van Aarde, R.J. \& Pimm, S.L., 2008, 'Rules of habitat use by elephants Loxodonta africana in southern Africa: Insights for regional management', Oryx 42(1), 66-75. https://doi.org/10.1017/\$0030605308000483

Hood, G.M., 2005, Poptools Version 2.6.6, viewed 01 June 2017, from http://poptools. org/

Johnson, J.B. \& Omland, K.S., 2004, 'Model selection in ecology and evolution', Trends in Ecology and Evolution 19(2), 101-108. https://doi.org/10.1016/j. tree.2003.10.013

Kerley, G.I., Geach, B.G. \& Vial, C., 2003, 'Jumbos or bust: Do tourists' perceptions lead to an under-appreciation of biodiversity?', South African Journal of Wildlife Research 33(1), 13-21.
Kinahan, A.A., Pimm, S.L. \& Van Aarde, R.J., 2007, 'Ambient temperature as a determinant of landscape use in the savanna elephant, Loxodonto africana', Journal of Thermal Biology 32(1), 47-58. https://doi.org/10.1016/j. jtherbio.2006.09.002

Lee, P.C., Fishlock, V., Webber, C.E. \& Moss, C.J., 2016, 'The reproductive advantages of a long life: Longevity and senescence in wild female African elephants', Behavioral Ecology and Sociobiology 70, 337-345. https://doi.org/10.1007/ s00265-015-2051-5

Loarie, S.R., Van Aarde, R.J. \& Pimm, S.L., 2009, 'Fences and artificial water affect African savannah elephant movement patterns', Biological Conservation 142(12), 3086-3098. https://doi.org/10.1016/j.biocon.2009.08.008

Osborn, F.V. \& Parker, G.E., 2003, 'Towards an integrated approach for reducing the conflict between elephants and people: A review of current research', Oryx 37(1), 80-84. https://doi.org/10.1017/S0030605303000152

Robson, A.S., 2015, 'Demographic responses to changes in conservation management: A case study on elephants in the Kruger National Park', MSc-thesis, University of Pretoria, Pretoria, South Africa.

Schutte, I.C., 1986, 'The general geology of the Kruger National Park', Koedoe 29(1), 13-37. https://doi.org/10.4102/koedoe.v29i1.517

Smit, I.P. \& Ferreira, S.M., 2010, 'Management intervention affects river-bound spatial dynamics of elephants', Biological Conservation 143(9), 2172-2181. https://doi. org/10.1016/j.biocon.2010.06.001

Trimble, M.J., Van Aarde, R.J., Ferreira, S.M., Nørgaard, C.F., Fourie, J., Lee, P.C. \& Moss, C.J., 2011, 'Age determination by back length for African savanna elephants: Extending age assessment techniques for aerial-based surveys', PLoS One 6(10), e26614. https://doi.org/10.1371/journal.pone.0026614

Valeix, M. Fritz, H., Sabatier, R., Murindagomo, F, Cumming, D. \& Duncan P, 2011 'Elephant-induced structural changes in the vegetation and habitat selection by large herbivores in an African savanna', Biological Conservation 144(2), 902-912. https://doi.org/10.1016/j.biocon.2010.10.029

Van Aarde, R.J., Jackson, T.P. \& Ferreira, S.M., 2006, 'Conservation science and elephant management in southern Africa', South African Journal of Science 102(9/10), 385.

Van Aarde, R.J., Whyte, I. \& Pimm, S., 1999, 'Culling and the dynamics of the Kruger National Park African elephant population', Animal Conservation 2(4), 287-294. https://doi.org/10.1111/j.1469-1795.1999.tb00075.x

Van Wilgen, B.W., Govender, N., Biggs, H.C., Ntsala, D., \& Funda, X.N., 2004, 'Response of savanna fire regimes to changing fire-management policies in a large African national park', Conservation Biology 18(6), 1533-1540. https://doi.org/10.1111/ j.1523-1739.2004.00362.x

Venter, F.J., Naiman, R.J., Biggs, H.C. \& Pienaar, D.J., 2008, 'The evolution of conservation management philosophy: Science, environmental change and socia adjustments in Kruger National Park', Ecosystems 11(2), 173-192. https://doi. org/10.1007/s10021-007-9116-x

Whyte, I.J., 2001, 'The conservation management of the Kruger National Park elephant population', PhD thesis, University of Pretoria, Pretoria, South Africa.

Young, K.D., Ferreira, S.M. \& Van Aarde, R.J., 2009a, 'Elephant spatial use in wet and dry savannas of southern Africa', Journal of Zoology 278(3), 189-205. https://doi. org/10.1111/j.1469-7998.2009.00568.x

Young, K.D., Ferreira, S.M. \& Van Aarde, R.J., 2009b, 'The influence of increasing population size and vegetation productivity on elephant distribution in the Kruger National Park', Austral Ecology 34(3), 329-342. https://doi. org/10.1111/j.1442-9993.2009.01934.x

Young, K.D. \& Van Aarde, R.J., 2010, 'Density as an explanatory variable of movements and calf survival in savanna elephants across southern Africa', Journal of Animal Ecology 79(3), 662-673. https://doi.org/10.1111/j.1365-2656.2010.01667.x 